\title{
THE PLACE OF KAITIAKITAKA WITHIN THE HEALTHCARE SYSTEM FOR MĀORIWHĀNAU FIGHTING LIFE-THREATENING ILLNESSES
}

\section{Stacey Gullen-Reynolds}

\author{
Ko tīhore te pō roa \\ Ko heia te kōpaka whakarākau ki Puari \\ Wero i te ninihi, Wero i te kokoto \\ Hei irika roimata mō kā huāka \\ Raraua te kiko e te niho makā \\ Ka puta ko te rei \\ Whakareia tō waka \\ Watua ki te toka \\ Aratakina tō kauika, he tira mōrehu \\ Aukaha, kia kaha, I kā kaha o Araiteuru \\ The long night has cleared \\ The hoar frost has set at Puari \\ The winter stars are above \\ A suspended mantel of tears for the relations \\ The flesh is mauled by the barracouta \\ The leader steps forward, Adorn your canoe \\ Go ahead to the south \\ Lead forth your pod \\ A party survivors
}

Strengthen the lashings of the bulwark of the Araiteuru

Outlined above is a mōteatea (lament) composed by Hana O'Regan for Moeraki whānau (family). It outlines two purposes. First, it talks of the journey of my tūpuna (ancestors) of Moeraki who travelled there from Kaiapoi pä(village) following an ambush by Te Rauparaha, serving as a reminder of the perseverance and strength of my tūpuna under the leadership of our Moeraki rangatira (leader), Maitiaha Tiramorehu. Secondly, it locates me within my whakapapa (genealogy) and tūrangawaewae (place of belonging) in Moeraki. My whānau (family) and I have wrapped the qualities and strengths of our tūpuna like a korowai (cloak) around us throughout our life journey. Moeraki is a place where I frequently return to be cleansed by its winds. I also pay homage to my tūpuna, who lie in the many urupā (cemetery), a further reminder of where I belong. 


\section{KUPU ARATAKI - AN INTRODUCTION}

I have spent a significant portion of my life transitioning from Te Ao Mārama (the world of light) to Te Pó (the darkness). Due to many experiences with my health, I am often scared there will come a time when I surrender to Te Pō, a constant reminder of my mortality and a deep desire to live. The following auto-ethnographic writing will reflect how I have experienced kaitiakitaka (care) as a person of Ngāi Tahu, Waitaha, and Ngāti Mamoe descent from the organisations and foundations responsible for caring for people fighting life-threatening illnesses.

\section{HE MIHI - ACKNOWLEDGEMENTS}

The motivation to understand how the distinctive cultural aspirations of Māori and the inequities Māori face within Aotearoa have been of interest to many Māori researchers. Amateur researchers like me are fortunate to stand on the shoulders of giants who have been trailblazers in Māori research. I acknowledge people such as Moana Jackson,' who called for transformational change within our criminal justice system, and Mason Durie, who has relentlessly advocated and contributed for transformational change within Māori advancement. ${ }^{2}$ Dr Rose Pere led significant transformation across many spheres of Māoridom including health, education, and language, and Dr Ranginui Walker, a prolific activist and academic, spent many years at the forefront of advocating for Māori interests. ${ }^{34}$ Closer to the subject at hand, there is growing research to understand how to reduce the disparities Māori face within the healthcare services related to the care and support they receive, including the Ministry of Health, ${ }^{5}$ Brewer, ${ }^{6}$ Slater et al. ${ }^{7}$

\section{DEFINING KAITIAKITANGA}

The following sentences define the term kaitiakitanga to provide a shared understanding for this article. The Māori Dictionary Online ${ }^{8}$ defines kaitiakitanga as guardianship, stewardship, and trusteeship. Elaborating further on its meaning is the following quote:

Kaitiakitanga embraces the spiritual and cultural guardianship of Te Ao Mārama, a responsibility derived from whakapapa. Kaitiakitanga entails an active exercise of responsibility in a manner beneficial to resources and the welfare of the people. It promotes the growth and development of the Māori people in all spheres of livelihood so that Māori can anticipate a future of living in good health and in reasonable prosperity.?

Based on these definitions, kaitiakitanga is about the responsibility to protect and care for the welfare of people and resources so that Māori may flourish.

\section{TŌKU REO,TŌKU OHOOHO: INDIGENOUS AUTOETHNOGRAPHY}

Indigenous researchers often find that indigenous approaches to research conflict with Western academia, which does not validate the personal voice as a way of knowing. ${ }^{10}$ Subsequently, this conflict could pose a challenge for a Māori woman who has 40 years of personal experience within the health system and wishes to validate my personal experiences through research. Yet 'auto-ethnography', a qualitative form of research, provides a way to theorise the researcher's experiences." Indigenous auto-ethnography is the ability to understand and explain "the nature of our own "cultural encounter," and as a form of cultural and critical consciousness ..."'2 Such a research approach is valid and empowering for indigenous researchers wishing to contribute to research-based indigenous experiences in colonial settings where there is limited research.

The following definition of indigenous auto-ethnography extends further by stating:

The "gift of indigeneity" lies in our ability to rediscover and recentre our culture from "within" as opposed to relying solely on 'externally codified' forms of knowledge that are often devoid of our own ways of knowing and doing. The journey is "deeply necessary" toward enabling an individual to spend time reflecting on their own cultural intellectual wisdom and to support individuals to recalibrate ones' own inner as well as collective cultural potential. ${ }^{13}$ 
Based on this definition, indigenous auto-ethnography is not only a validated way of knowing but is essential in the reclamation of our cultural knowledge and understanding, providing space for indigenous peoples to reclaim our knowledge and experiences within the research process. Based on this research method, I can position my experiences and cultural encounters as a form of data to help inform the topic of this essay - my experiences of kaitiakitaka within the healthcare system.

\section{MĀORI VERSUS WESTERN APPROACHES TO HEALTH}

Before colonial arrival, health within Māori society was considered all-encompassing of wairua (spiritual), whānau (family), hinengaro (mental), and tinana (physical aspects). Matters of whenua (land), Te Ao Türoa (environment), Te Reo (language), whanaungatanga (connection) were also considered central to Māori health. ${ }^{14}$ Such holistic practices are often at odds with Western approaches to health, where instead, effort is placed on diagnosing symptoms, physical examinations, medical history, and tests, a process underpinned by science and technology. ${ }^{15}$

As a result of such differing world views, Western approaches to medicine negatively impacted Māori health. At the commencement of colonial settlement, estimates project the Māori population was between 90,000 and 200,000. By 1874, the Māori population had plummeted to 45,470 people. ${ }^{16}$ Such poor health outcomes for Māori were a stark contrast from when colonial settlers first arrived on the shores of Aotearoa. Early written evidence depicts Māori as a strong people who were in good physical condition. There was no evidence that Māori population rates were declining because there were few epidemic diseases, and sanitation was carefully managed. ${ }^{17}$

The previous good health Māori had maintained altered significantly due to the onslaught of colonial diseases that traditional health practices could not cure. A further challenge that would provide a fatal blow was the Tohunga Suppression Act 1907 ('the Act'). Its purpose was to bring an end to the practice of tohunga (healers) captured in part in the following passage:

Every person who gathers around him by practicing on their superstition or credulity, or who misleads or attempts to mislead any Māori by professing or pretending to possess supernatural powers in the treatment or cure of any disease, or in the foretelling of future events. ${ }^{18}$

There were several motivations to have this Act passed into law. Maui Pomare, a well-respected Māori doctor, believed that traditional rongoa (medicine) and tohunga practices resulted in needless deaths. The Act was also politically motivated to undermine Tuhoe leader, Rua Kenana, a recognised healer and prophet. Rua Kenana had a considerable following and prophesied that Europeans would return to where they had come. ${ }^{19}$ Regardless of the motivating factors, the Act significantly impacted traditional Māori approaches and practices in health.

The continued inequities found within the health system have resulted in a contemporary inquiry into Māori health. The report resulting from the investigation is entitled "Health Services and Outcomes Kaupapa Inquiry (Wai 2575)."'20 The findings established that the state of health for Māori is unacceptable, and responding with effective solutions must be a high priority. The report ascertained Māori face significant inequities across many health outcomes, including having the highest mortality rate. While many factors contribute to Māori health outcomes, an important aspect is social determinants: income, poverty, employment, education, and housing, interconnected with the impacts of colonisation. ${ }^{21}$

New Zealand has a health system that values Western values, practices, and culture, placing Māori at the periphery. And this is where my story comes in. My account is not so much reflective of the inequities of access to services and treatments. Instead, it focuses on how I have experienced kaitiakitaka within a New Zealand health system that values Pākehā norms, and subsequently, the inequities for Māori accessing services and support that reflect Māori standards in the face of life-threatening illnesses. 


\section{A PERSONAL NARRATIVE OF MY JOURNEY INTHE HEALTH SYSTEM}

\section{Mate Pukupuku - Surviving Childhood Cancer}

My journey in the healthcare sector began when I was two years old. My mother was concerned about the colour of my urine and how unsettled I had become. Following a series of appointments, I was diagnosed with Stage 4 Wilms tumour, a rare cancer of the kidneys prevalent in young children. ${ }^{22}$ Stage four cancer meant that it had started spreading to other organs, such as the lungs, liver, bones, and brain. There is a common conception that childhood cancer is rare. However, evidence suggests that three children a week are diagnosed with cancer, one in every 285 children ${ }^{23}$ will be diagnosed with a form of cancer, and one out of five will not survive. ${ }^{24}$

I do not have many recollections of this time in my life. My reflections rest with my mother, a 19-year-old solo parent, who had little in the way of support. For this reason, I considered that my cancer was my mother's journey. Though I was fighting off the disease, my mother stayed faithfully at my side, navigated and advocated for me within the healthcare system, and did not lose faith when doctors informed her that she needed to prepare for my passing. Due to the length of time I was unwell and receiving treatment, my mother could not work, study or pursue any of her interests. I was her world; she was mine. If nothing else, this was a lesson of a mother's undying love and reflects that one person's health experience is, in fact, a whānau journey.

\section{Roro Ikura - Surviving a Stroke}

In late January 20 I I, I had driven to Christchurch for a whānau celebration. Work had been hectic, so when I arrived, I was exhausted. I said good night to my whānau and had an early night. I woke up early the following day to feel intense pins and needles down the left side of my body. I knew I had had a stroke. I remember very little afterwards apart from the feeling of embarrassment being carried away in an ambulance.

The impact of the stroke had many consequences. The first was the impairment to my motor skills and cognitive ability: I lost my left peripheral vision, the feeling on my left side, significant impairment to my short-term memory, facial recognition, and significant fatigue. The ability to do the most straightforward tasks became hard and remembering the most mundane things was impossible. The possibility of returning to work was minimal. I was not allowed to drive, and I was not even allowed to be left alone. I had suddenly become dependent on others, particularly the healthcare system and my whänau, who were charged with my rehabilitation, re-teaching me the simplest of tasks, and slowly supporting my return to employment. Throughout this chaos, I am only able to recollect a few memories. This one time, I remember my uncle taking me to the shoe shop to buy me some appropriate shoes to gain my confidence in walking again. Unable to tie my shoelaces or even place the shoes on my feet, he patiently did this for me while holding me up while I walked around the store. Being a typical male, my uncle was not particularly overjoyed to be in a women's shoe shop. Still, fortunately for me, his love for me outweighed his unease. This love would also come in handy later when he would re-teach me how to drive.

\section{Mate Ūtaetae - Breast Cancer}

In 2017, I had arranged an overseas adventure. A week before my departure, I visited my doctor for a regular check-up. During the appointment, I asked my doctor to check my breasts. Upon examination, my doctor found a lump under my left breast. My doctor reassured me that lumps in the breast were common, but she would refer me for a mammogram. Not wishing to have this on my mind during my trip, I went to a private hospital. After my first mammogram, I was asked to have another.After my second mammogram, I attended an ultrasound. Feeling anxious, when I walked into my ultrasound, I was met by a woman who proclaimed that it was her that had undertaken my ultrasound that identified my Wilms tumour, the cancer I was diagnosed with at the age of two years old. I knew this was a tohu (sign). 
In the days that followed, I cancelled my dream holiday and attended many appointments to make sense of the unknown. I remember after the biopsy waiting with my whänau to determine the stage of my cancer. When the doctor arrived in the room, she informed my whänau and me that I had Stage 2 breast cancer. The cancer stage meant that it was small and had only spread to the axillary lymph nodes. The doctors advised me that if I underwent a series of procedures, the chance of eliminating the cancer was highly probable.

I would compare the next few weeks to working on a puzzle; you cannot see the entire picture until all the information is in place. I had to make life-impacting decisions about my course of treatment and mentally prepare for surgery while making sense of all the information.

During this time, there was always a whānau member there with me. Like me, they were trying to make sense of all of the information while trying to reconcile their own emotions. I remember one time, during an appointment with an oncologist, feeling my Dad's hand rest on my thigh. What may seem like a simple gesture to many was a decisive moment for me personally, from a man who avoids any form of emotion. I remember clearly how red his face had become and knowing how very powerless he was feeling. There was nothing in his power he could do to free his daughter of the uncertainty and emotion that comes with knowing that you have cancer. I could do nothing to comfort him from the thoughts that he may lose his daughter to cancer.

In the weeks that would follow, I would undertake a course of treatment that included an operation to remove cancer, radiation, and five years on the medication, Letrole, to reduce the risk of cancer returning.

\section{KAITIAKITAKA - EXPERIENCES OF CARE DURING TREATMENT AND RECOVERY}

\section{Kaitiakitaka and childhood cancer}

During my treatment as a young child, the doctors and nurses were always supportive of my mother and me. There was never any doubt of their commitment to my survival. Research shows that it is a profoundly personal journey when a child has cancer for all health staff involved. It is intense dealing with patients' and loved one's emotions and how medical staff deal with their emotional responses. ${ }^{25}$ I remember, throughout my childhood, being warmly greeted by the many doctors and nurses. These people became a part of our extended whānau, and we were united by a common goal, ensuring my survival. The feelings of aroha (love) and manaaki (care) that I experienced stand as a testament to the emotional connection the healthcare staff had developed, far exceeding the expectations of a typical employee in a nine-to-five job.

Though the medical team's level of support and care has never been in question, my mother recalls no direct support offered that reflected our culture, language, and practices. Admittedly, my mother gave it little thought; her focus was on her child's survival. ${ }^{26}$

What is a topic worth further reflection, is the development of a child's identity. O'Regan's ${ }^{27}$ definition of identity states: "The concept of identity is explained as a person's sense of belonging: of knowing and understanding your individuality and your place in the world, where you fit in and the relationships that you have with others." ${ }^{28}$ Based on this definition, identity is shaped through belonging, relationships, and coming to understand one's unique place in the world. Jenkin's ${ }^{29}$ research looks at the identity development of younger children and contends that when a baby becomes familiar with the world around it, their identity is influenced by external signals such as gendering, clothes, and toys. By the age of two, children develop the ability to talk and mimic and re-enact the people around them. By the age of five, the child begins to understand the role and position they hold. This knowledge leads to developing a public face to control how others perceive them.

Subsequently, if a Māori child spends a significant part of their childhood in a hospital where Pākehā practices, values, and people are the norm, they will see themselves as belonging to these same ideals. Therefore, a health system that provides a culturally rich environment conducive to cultural identity is central to enacting their responsibilities of kaitiakitaka for Māori whānau in their fight against cancer. 
Research by Slater et al. ${ }^{30}$ revealed that primary care, culturally responsive practices, and continuity of care throughout the cancer journey are significant for Māori. Evidence also suggests that Māori organisations often fill this gap by facilitating access to resources, information, and services. Slater's research also illustrated that it is essential that there is a positive relationship with the general practitioner, resulting in greater access to resources and support. The role of whānau is also significantly important. The research showed that one whānau member often becomes the primary tangata kaitiaki (care person), leading to burnout and financial strain. ${ }^{31}$ The point is that research clearly shows that providing culturally responsive support services is fundamental in enacting the responsibilities of kaitiakitaka to whānau who are fighting life-threatening illnesses.

\section{National Cancer Support Services}

The hospital and healthcare services are not the only organisations tasked with the kaitiaki of whānau fighting lifethreatening illnesses. Receiving no direct funding from the government, the Child Cancer Foundation ${ }^{32}$ supports children and their whānau throughout the cancer journey by providing a holistic wrap-around support service. Examples include family support coordinators, who provide holistic wrap-around support reflective of whānau needs. The Child Cancer Foundation is mindful of cultural nuances, observing tikanga as directed by Māori whānau. However, no resources or programmes have been developed explicitly for Māori. ${ }^{33}$

\section{Kaitiakitaka and Strokes}

Before my experience, I knew very little about strokes. I had heard of other people who had passed away or were stroke survivors, people all much older than I. It seemed implausible that I would fall victim to the same fate, only to learn that a stroke does not discriminate. Research has illustrated that over I I,000 people have a stroke a year, with 25 to 30 per cent of these people being under the age of 65 years old. Strokes are New Zealand's second-highest cause of death and the leading cause of severe disability for adults. ${ }^{34}$ Research also shows Māori are at more risk of having a stroke than non-Māori. ${ }^{35}$

Following my stroke, I sought out support services in my location that were responsive to Māori stroke survivors to no avail. I have since identified that I had not been alone in my quest. A group named Te Tino Rangatiratanga o te Mate Ikura Roro developed due to the lack of support that is responsive to Māori. Its premise is to support Māori stroke survivors to have tino rangatiratanga over their own lives, underpinned by research that found that mainstream services do not work for Māori. These services fail Māori, partly because they are too difficult for Māori to access and because the supports provided are not what Māori need. The research also revealed that the skills and motivation to lead and develop initiatives are within the stroke community itself. ${ }^{36}$ Another such example is the Awhi Mai Trust established by Ngāti Whakaue researcher Rukingi Haupapa. Based in Rotorua, Rukingi suffered a stroke over 15 years ago. Rukingi now supports Māori stroke survivors and their whānau by offering advice and connecting them to support services. ${ }^{37}$ These examples show Māori having to respond to the need to provide kaitiakitaka to Māori stroke survivors because of limited support available that is responsive to Mãori needs in this area.

\section{The Stroke Foundation New Zealand}

The Stroke Foundation New Zealand is a charity dedicated to stroke prevention and recovery. Examples of how the Foundation provides kaitiakitaka to survivors and whänau include access to stroke advisors who aid in recovery and accessing services that support rehabilitation. The 'Return to Work Advisors' is a further example of a service the Foundation provides. Currently based in Auckland and Christchurch, this role is responsible for supporting the transition of stroke survivors back to work. The practice of stroke advisors is guided by Te Pae Mahutonga, a health framework developed by Durie ${ }^{38}$ to help stroke survivors have autonomy over their health outcomes. The foundation has also prioritised Māori and actively seeks to ensure that resources and services are culturally responsive and engages with Māori communities. The foundation also established the National Māori Health Advisor role in 2013 to ensure that Māori are experiencing a high level of kaitiakitaka responsive to their needs. ${ }^{39}$ 


\section{SOURCES OF CULTURALLY RESPONSIVE SUPPORT AND RESOURCES FOR MĀORIWOMEN BREAST CANCER SURVIVORS}

The statistics around Māori and breast cancer are sobering. Evidence shows that Māori women are 21 per cent more likely to be diagnosed with breast cancer, 30 per cent less likely to be diagnosed early, and 72 per cent of Māori women are more likely to die from breast cancer than non-Māori women. ${ }^{40}$ However, many organisations work to ensure that women are supported throughout their breast cancer treatment. Examples from my journey through breast cancer included going fly-fishing, an event facilitated by Casting for Recovery. ${ }^{4 \mid}$ A further opportunity presented was to participate in an exercise programme facilitated by the University of Otago for women fighting breast cancer. The programme is founded on research that exercise reduces implications related to breast cancer while aiding women in the fight against cancer. ${ }^{42}$ The Breast Cancer Foundation also provides a website that includes relevant information and resources, including a booklet written in Te Reo Māori about breast cancer. ${ }^{43}$

There are several community organisations providing kaitiakitaka to Māori women fighting breast cancer. In Rotorua, a voluntary support group named Aroha Mai Cancer Support Services has been formed due to limited Māori cancer support groups in the area. ${ }^{44}$ Waipareira Trust employs Community Cancer Navigator, a free service available to Māori over 16 years old. The navigator supports whānau to access community supports, ongoing support via phone calls, and face-to-face meet and greets. ${ }^{45}$ In the South Island, Nelson Marlborough Health also has developed resources such as a booklet, brochures, and videos of Māori celebrities that have survived cancer. ${ }^{46}$ From the examples listed here, there is no commentary on how effective Māori women find these services, making this a topic that needs to be explored further.

The level of targeted support for Māori from organisations throughout the country differ, along with how they prioritise their support services for Māori. Although it is not the topic of this article, further research in understanding the responsibilities that organisations have in New Zealand as treaty partners would be worthy of further investigation.

\section{SUMMARY}

I have faced significant health issues throughout my life, a constant reminder of my mortality. Through these experiences, I have developed a personal understanding of how kaitiakitaka is given effect throughout the health system and by organisations tasked with people's care. The Health Services and Outcomes Kaupapa Inquiry ${ }^{47}$ presented by The Waitangi Tribunal has highlighted the inexcusable inequities that Māori continue to face throughout the health system due to colonialism and the systematic failures that have followed. Growing research illustrates the importance of responsive kaitiakitaka practices in supporting whānau during these challenging times. This need for change does not negate the significant support that many health professionals provide, with research highlighting that caring for potentially terminally ill people is a deeply profound experience for medical staff. Yet this care is often delivered from a Western perspective that does not reflect a Māori worldview. Although there are several organisations in New Zealand, practices are not consistent in how responsive kaitiakitaka is prioritised. This article has also highlighted that communities are taking charge of developing support networks and supporting themselves due to limited resource responsive resources. This körero, if anything, has established the need for further research in this area.

In conclusion, this article has reminded me of the love of whänau: my uncle who tied my shoes when I could not; the gentle gesture of my father placing his hand on my lap; the eternal love of my mother and all she sacrificed; the many doctors and nurses who fought for my life. Kaitiakitaka, in my experiences, has been the small pockets of light that shine through the darkness. This article calls for an approach to kaitiakitaka for whānau Māori fighting life-threatening illnesses where our cultural values, practices, and language are not compromised because of fighting for survival. 
Stacey Gullen-Reynolds (Kāi Tahu, Waitaha, Ngāti Mamoe) MlndS, has a background in number of regional, national, hapū and iwi roles. Stacey hails from Moeraki, and is a committed, dedicated member of her community, supporting her marae, whānau, hapū. Stacey is a facilitator for Capable NZ working with iwi cohorts and individual learners. Currently studying towards a Doctorate of Professional Practice, Stacey's interest in research include Kaupapa Māori research, Māori equity and education.

I M. Jackson, "The Maori and the criminal justice system - new perspective: He whaipaanga hou," (Study Series I8, Part I, Policy and Research Division, Department of Justice,Wellington, 1987), https://www.ojp.gov/pdffiles I/Digitization/I08675NCJRS.pdf.

2 Mason Durie, Launching Māori Futures, (Wellington, New Zealand: Huia Publishers, 2003); Mason Durie, Navigating Māori Futures, (Wellington, New Zealand: Huia Publishers, 20I I).

3 R. Walker, Ngā Pepa a Ranginui:TeWalker Papers, (Auckland: Penguin Books, 1996);

4 R. Walker, Ka Whawhai Tonu Mātou: Struggle without End, (Auckland: Penguin Books, 1990).

5 Ministry of Health, Community Cancer Support Services, "Pilot Project Evaluation: Final Completion Report," (Wellington, New Zealand: Ministry of Health, 201 I).

6 Brain Research New Zealand, "Te Tino Rangatiratanga o te Mate Ikura Roro: Empowering Stroke Survivors," April 29, 20। 9, http://www.brnz.ac.nz/news-events/te-tino-rangatiratanga-o-te-mate-ikura-roro-empowering-stroke-survivors.

7 T. Slater et al., "It's Whanaungatanga and all that Kind of Stuff: Māori Cancer Patients' Experiences of Health Services," Journal of Primary Healthcare, 5 no. 4 (2013): 308-3। 4.

8 Māori Dictionary, "kaitiakitanga," Te Aka Online Māori Dictionary, (accessed August II, 202 I) https://maoridictionary.co.nz/sear ch?idiom=\&phrase=\&proverb=\&loan=\&histLoanWords=\&keywords=kaitiakitanga

9 Lakes District Health Board, "Māori Health Guide Principles," (July I2, 20 I 7) http://www.lakesdhb.govt.nz/article.aspx?id= I 023

10 S. L. Tuhiwai, Decolonizing methodologies: Research and indigenous peoples (Dunedin: University of Otago Press, 1999).

I I Sarah Wall, "Easier Said than Done:Writing an Autoethnography," International Journal of Qualitative Methods 7 no. I (2008), https://journals.sagepub.com/doi/pdf/10.1 I77/160940690800700103.

12 P.Whitinui, "Indigenous autoethnography: Exploring, engaging, and experiencing "self" as a Native method of inquiry," Journal of Contemporary Ethnography 43 no. 4 (2014): 456-487.

13 Royal, 2009, as cited in Whitinui, "Indigenous autoethnography".

14 I. Ramsden, The Treaty of Waitangi (n.d.), [Course Notes].

I5 C. C. Chang et al., "A correlation between pulse diagnosis of human body and health monitoring of structures," Earthquake Engineering and Engineering Vibration, 3 no. I (2004): 117.

16 C. Orange, The Treaty of Waitangi (Bridget William Books Limited:Wellington, 1990).

17 Ramsden, The Treaty of Waitangi.

18 Durie, Navigating Māori Futures, 316.

19 Ibid.

20 The Waitangi Tribunal, "Hauora: Report on Stage One of the Health and Services and Outcomes Kaupapa Inquiry," (Wai 2575 Waitangi Tribunal Report), (Legislation Direct: Lower Hutt New Zealand, 2019).

21 Ibid.

22 Cancer:Net "Wilms Tumour - Childhood," (accessed on April 09, 2021) https://www.cancer.net/cancer-types/wilms-tumorchildhood/statistics.

23 As a side note, Māori children are no more likely to be diagnosed with cancer than children of other ethnicities (Ministry of Health, n.d).[the $\mathrm{MOH}$ reference needs more detail as you do not have an endnote for the Ministry with "n.d.']

24 University of Otago, Centre for Translational Cancer Research, "REACH: Child Cancer," (accessed August II, 202 I) https:// www.otago.ac.nz/ctcr/research/childhood-cancers/otago6 |7|36.html. 
25 T. McConnell et al.," "Healthcare Staff Experience of Providing End-of-Life Care to Children:A Mixed Method Review," (Belfast: Queen's University Belfast, 20 I6), http://eprints.bournemouth.ac.uk/26343///Porter_Healthcare_Staff_Experience.pdf.

26 D. Reynolds, personal communication, May 0I, 2021.

27 H O'Regan, Ko Tahu, Ko au: Kai Tahu tribal Identity (Christchurch: Horomaka Publishing, 200 I).

28 Ibid.

29 Jenkin (2014) [this note needs more detail - eg title, publisher and location if a book, journal volume and issue if from a periodical]

30 Slater, "It's Whanaungatanga and all that Kind of Stuff."

31 Ibid.

32 Child Cancer Foundation, "Child Cancer Foundation," (accessed March 21, 202I) https://www.childcancer.org.nz/.

33 Child Cancer Foundation, personal communication, 2021.

34 Stroke Foundation New Zealand, "Facts About Stroke in New Zealand," (accessed March 30, 2021) https://www.stroke.org. nz/facts-and-faqs.

35 Southern Cross New Zealand, "Stroke - symptoms, treatment, prevention," (accessed March 30, 202I) https://www. southerncross.co.nz/group/medical-library/stroke-symptoms-treatment-prevention.

36 Brain Research New Zealand, "Te Tino Rangatiratanga o te Mate Ikura Roro."

37 Jessica Tyson, "Stroke Survivor Hosts Hui in the Bay of Plenty to Support Whānau," Te Ao Māori News, August 31, 2020, https:// www.teaomaori.news/stroke-survivor-hosts-hui-bay-plenty-support-whanau.

38 M. Durie, "An indigenous model of health promotion," Health Promotion Journal of Australia I5 no. 3 (2004): | 8 | - I 85.

39 N. Brown, personal communication, March 31, 2021.

40 Breast Cancer Aotearoa Coalition, "Breast Cancer in Māori and Pasifika Women," (accessed June I5, 202I) https://www. breastcancer.org.nz/Support/Maori-Pacifica/stats.

4I Owen River Lodge, "Casting for Recovery 2020: how we helped make it work in the Covid year," (October 26, 2020) https:// www.owenriverlodge.co.nz/blog/casting-for-recovery-2020-how-we-helped-make-it-work-in-the-covid-year/.

42 University of Otago, School of Physical Education Sport and Exercise Sciences, "Exercise Training Beyond Breast Cancer (ExpinktTM)," (accessed August I I, 202 I,) https://www.otago.ac.nz/sopeses/outreach/expinkt_clinic.html.

43 Breast Cancer Foundation, "Breast Cancer Foundation," (accessed March 30, 202I) https://www.breastcancerfoundation.org. $n z$.

44 Aroha Mai Cancer Support Services, "About Aroha Mai," (accessed March 25, 2021) http://www.arohamai.maori.nz/about. html.

45 Waipareira Trust, "Mātua," (accessed March 25, 2021) https://www.waipareira.com/free-services-for-you-and-your-whanau/ matual.

46 Nelson Marlborough Health, "Cancer Screening and Support Services: Kaupapa Māori Cancer Support Services," (accessed March 25, 202I) https://www.nmdhb.govt.nz/health-services/community-and-outpatient-services/cancer-screening-andsupport-services/kaupapa-maori-cancer-support-services/.

47 The Waitangi Tribunal, Hauora. 